\title{
The Medical Pamphlet and Pamphleteering in Canada
}

Jennifer J. Connor ${ }^{\dagger}$

Pamphlets comprise the earliest, most enduring form of medical literature published in Canada. ${ }^{\mathrm{I}}$ First appearing in the late eighteenth century - some thirty years after the arrival of the printing press to the Canadas ${ }^{2}$ - they have played a conspicuous role in the history of both Canadian medicine and Canadian medical publishing. The emergence of Canadian medical books in the middle of the nineteenth century did not displace the pamphlet literature, which evolved and has continued to appear to the present.

Reasons for the endurance of medical pamphlets lie partly in their value as a medium for conveying information quickly and cheaply, especially to lay readers. More importantly, they fulfil a particular rhetorical function that differentiates them from books and other publications. As the following discussion will show, regardless of their subject, the primary goal of medical pamphlets was to encourage or persuade readers to take a particular course of action. From the eighteenth to the twentieth centuries, this aim is manifest in Canadian pamphlets dealing with disease and its prevention and in those advocating alternative forms of medicine.

Pamphlets have traditionally been viewed, by historians and bibliographers alike, as books writ small. Described bibliographically as imprints along with books or used as primary evidence of historical events, pamphlets have seemed to differ only in their external form. Indeed, supporting this view have been rigid cataloguing definitions of the pamphlet based on its physical structure, notably its unbound state and number of pages. Only recently have scholars attempted to understand the role and function of pamphlets in a cultural context; generally speaking, current attempts to define the pamphlet focus on its polemical nature. Thus, for example, an

$\dagger$ Jennifer J. Connor is a Hannah Postdoctoral Fellow in History of Medicine at McMaster University. The Social Sciences and Humanities Research Council of Canada and the Hannah Institute for the History of Medicine provided financial support for her research on Canadian medical publishing. 
examination of pamphlets in the sixteenth- to seventeenth-century Dutch Republic derives from the insight that pamphlets were persuasive, printed writings 'of immediate and direct or indirect political significance': they could be long, but were 'usually brief because of [their] immediate relevance and hasty character.' 3 Similarly, Yves Avril has defined the pamphlet as a writing triggered by an immediate circumstance which unilaterally attacks an individual, group of individuals, an idea, or an ideological system; furthermore, the pamphlet emphasizes the disclosure of truth. ${ }^{4}$ Contrasting the pamphlet with the book, a nineteenth-century observer also commented:

the chief notes of a pamphlet are brevity and spontaneity. It has a distinct aim, and relates to some matter of current interest, whether religious, political, or literary. Usually intended to support a particular line of argument, it may be descriptive, controversial, didactic, or satirical. It is not so much a class as a form of literature, and from its ephemeral character represents the changeful currents of public opinion more closely than the bulky volume published after the formation of that opinion. ${ }^{5}$

In short, the pamphlet is a distinct literary genre.

This functional view of the pamphlet not only provides a useful context for the study of the medical pamphlet in Canada, but it also narrows its scope by excluding publications which, though small or ephemeral, do not meet the rhetorical criteria for pamphlet literature. Such imprints as might otherwise be considered pamphlets include legislative acts, ordinances, and related documents; institutional announcements, by-laws and annual reports; lectures, conference proceedings or transactions, and ceremonial addresses; catalogues; almanacs; promotional literature; and offprints. ${ }^{6}$ Viewing the pamphlet as a highly focused, timely and politically actuated document published for the public at large also allows inclusion of longer imprints which, though clearly not books, fall outside the physical limitations usually imposed for pamphlets. As well, this functional definition extends to works which by their form and frequency might be deemed serials or journals - an error which has led to both confusion about their purpose among some historians and invidious comparisons made with recognized conventional forms such as the medical journal.

The following discussion, then, concerns itself with trends in medical pamphleteering in Canada. It is impossible to know for 
certain how many medical pamphlets were published in this country; nevertheless, those surviving offer insights into reasons for their appearance, the nature of their authorship, and the implicit role of their printers.

It is the author's motivation that generates both pamphlet literature and the process of pamphleteering. Authorship of Canadian medical pamphlets encompasses both individual and collective approaches, but more importantly, it too relies on the external context for writing: in each case social, political and intellectual forces provided the stimulus for authors to write. Generally speaking, they wrote for two main reasons: to disseminate information quickly about disease and its treatment or prevention; and to respond to current issues in the development of the medical profession itself.

From the eighteenth to the twentieth centuries, innumerable pamphlets attempted to inform Canadian readers about a particular disease and its possible modes of treatment. Meeting some of the rhetorical criteria for pamphlet literature, they frequently presented timely information in response to an urgent situation in the community, the spread of disease. Moreover, they illustrate the role of the pamphlet in public debate by arguing the cause or nature of the disease. For instance, two pamphlets in the 1780 os regarding the $\mathrm{Mal}$ de la Baie St-Paul disagreed on its nature, notably whether or not it was venereal. ${ }^{7}$ Later pamphlets appearing during outbreaks of cholera in Canada typically took either the official stance of the government, or the personal perspective of practitioners who experienced the disease first-hand. ${ }^{8}$ These latter pamphlets in particular illustrate ways in which individual authors reacted to cholera as a scientific, spiritual, or commercial problem. In his large pamphlet published in I 835, Elam Stimson addressed both lay readers and his medical colleagues, not only on methods of treating cholera, but also on his own theory about its cause. ${ }^{9}$ Another author later drew on his background as physician and minister to exhort his audience to make peace with God. ${ }^{10}$ His pamphlet reflects a tradition of marrying religion and medicine in popular works on disease. ${ }^{\text {II }}$ Finally, a chemist in Montreal capitalized on public fear of disease to promote the sale of his 'Gouttes anti-cholériques. ${ }^{\prime 2}$

Perhaps the one disease inciting most intense and orchestrated pamphleteering in Canada - including clear lines drawn between opponents and proponents of the methods for its prevention and treatment - was smallpox. Indeed, outbreaks of smallpox in this country stimulated fewer writers to comment on the disease itself 
than to argue for or against its prevention through vaccination. In I 875, for example, J. Emery-Coderre in Montreal refuted the claims of a recently published article in favour of vaccination by citing worldwide authorities who viewed it as a fraud. ${ }^{13}$ More dramatically, in I 882 a lay writer in Toronto routinely entered the vaccination debate. Although David Edwards began writing his pamphlets, which he called collectively Medical Criticism, to present alternative modes of medical treatment to the public, he quickly made vaccination his hobbyhorse, asking 'How much longer will the docile people of Ontario be content to be hoodwinked by the doctors?'I4 Reacting to recent legislation establishing a central board of health to implement the longstanding vaccination and inoculation act, Edwards launched a pamphlet campaign in which he quoted well-known figures on their opposition to vaccination laws and on the dangers of vaccination itself. In his own remarks, Edwards used a rhetorical scheme - symploce - to emphasize the failures of medical claims for vaccination: beginning each claim with 'Doctors . . . discovered,' he simply added the refrain 'The People find that it does not..'15 Later he charged

The Doctors discovered that a Small-pox panic was worth ten million dollars, in the form of Vaccination Fees and medical attendance on the re-vaccinated sufferers.

Which the People cannot deny.

The Doctors discovered that by a liberal expenditure of the Public Funds in posters, handbills, memoranda, and advertisements, this panic could be maintained.

The People have found the same.

The Doctors have discovered that in order to keep up Vaccination, the articles of the Vaccine Creed must be changed every year.

The People find the same.

The Doctors found that the people would not submit to Vaccination without coercion by fines, seizure of goods, or imprisonment.

From which enslavement the People demand deliverance. ${ }^{16}$

Through such incremental repetition, Edwards pressed his point that vaccination represented nothing less than a way to enslave 'the People.' Later Edwards ended his personal attack by asking again, 'How long will Canadians submit to have their children's blood poisoned, and their health and future happiness jeopardised, in order that MEDICAL THEORIES MAY PREVAIL, and MEDICAL DOMINATION BE MAINTAINED?'I7 
That vaccination - especially compulsory vaccination - against smallpox could elicit such an emotionally charged response was not unusual, and in fact Edwards's paper campaign was mild compared with events in Montreal three years later. In I 885 , riots occurred among French Montrealers because they believed compulsory vaccination during the smallpox epidemic was an Anglophone conspiracy. ${ }^{18}$ William Hingston, a prominent Montreal surgeon, therefore felt compelled to publish a pamphlet, in English and French versions, arguing in favour of vaccination 'to meet the objections' of colleagues against its practice. For the benefit of his French colleagues, Hingston quoted extensively from continental rather than British sources to buttress his point, 'because it has been asserted at public gatherings in this city, that it was an "English" remedy, and that Englishmen had a pride in engrafting their "beastly" virus on the Christian children of fair Canada!'19 The circumstances surrounding the writing of this pamphlet, then, involved not only a political sense of oppression, but a cultural one as well.

The vaccination issue did not become less charged in the twentieth century, if anything growing more polarized along political lines. ${ }^{20}$ Reflecting bureaucratization of the issue, pamphlets increasingly were issued by government agencies. In 1905, Charles A. Hodgetts wrote $A$ Descriptive Article on Smallpox with 20 Illustrations not for the public, but for his own colleagues who had apparently been misdiagnosing cases of smallpox in Ontario; the pamphlet was issued by the Provincial Board of Health of Ontario. ${ }^{2 I}$ Later, however, J.J. Heagerty, a member of the federal Department of Health, wrote 'A Popular Treatise' on Small-Pox and Vaccination. ${ }^{22}$ Both pamphlets included photographs of smallpox sufferers to underscore the seriousness of the disease to medical and lay readers alike.

A direct backlash to such government-sponsored literature and the officially imposed regulations for the prevention of smallpox arose with the creation of anti-vaccination leagues. The pamphlet literature of these groups could be strident and inflammatory, as witnessed by the Official Bulletin of the Anti-Vaccination and Medical Freedom League of B.C., called simply The Alarm. Published in Vancouver in 1925, this pamphlet differed from others in its newspaper form and layout, but its intended audience and message were clear: Vancouver parents must realize that they have the right to exempt their children from vaccination under the law. Characterizing the family doctor not only as a 'Licensed Thug' who 'makes vaccination a condition for teaching and other professions, ${ }^{23}$ but 
also as an 'irresponsible disease grafter,' the pamphlet declared the physician 'has a strangle hold upon the machinery of the State. He is a traitor to the democratic spirit of the British Constitution.' Moreover, it argued that 'Compulsory State Medical Insurance Means Medical Conscription. A Medical Monopoly Robs You of Your Choice of Physician. Get Medical Freedom First to Secure Self Ownership.' The Alarm called upon men and women of Vancouver to act:

why allow political doctors to run you and spread abroad false statements that are allowed in the press without a chance to contradict except at hearty advertising rates? Help to smash once for all this modern curse of tainting healthy children with disease. DO IT NOW.

Disease thus acted as a catalyst for pamphlet writing in Canada up to the r920s. Owing to the urgency of the situation, authors both lay and medical wrote for the general populace primarily to inform about the disease and any means for its prevention. They often identified their intended readership in pamphlet titles or prefaces to ensure that they reached the right audience /Stimson's Cholera Beacon . . . Designed for Popular Instruction; an M.D.'s Popular Lecture on cholera; the Conseil Provincial d'Hygiène's Conseils pratiques aux familles on cholera; and Heagerty's Popular Treatise on smallpox). For at least the first half of the nineteenth century, their full titles often served as abstracts of the whole work, implicitly to attract a popular audience; for example,

The Cholera Beacon: Being a Treatise on the Epidemic Cholera: As It Appeared in Upper Canada, in I 832-4, with a Plain and Practical Description of the First Grade, or Premonitory Symptoms, and the Various Forms of Attack, by Which the Disease May Be Detected in Its Curable State, Together with Directions for Successful Treatment. Designed for Popular Instruction.

Some authors did write for medical colleagues: not simply triggered by circumstance, their pamphlets were argumentative, attempting to persuade other practitioners - as in the cases of Emery-Coderre, Hingston, and Hodgetts. Up to the end of the nineteenth century, authors were usually independent individuals presenting their personal views on the disease, although government sponsorship of pamphlets existed from the start with the 1785 pamphlet on the Mal 
de la Baie St-Paul and later pamphlets issued on cholera. By the I920s, disease pamphlets were almost entirely written and sponsored by government agencies and lay organizations (such as anti-vaccination societies). Most significantly, these pamphlets demonstrate public debates in action as they employ rhetorical techniques to persuade readers.

In addition to writing about disease, a major motivation for authors came from changes within medicine itself and its practice. The most important issues facing medical practitioners throughout the nineteenth century involved differing, often antagonistic, systems of medical therapeutics. The ongoing demands of these competing systems for attention meant that the pamphlet became the favoured medium for communication to lay and medical audiences alike. Basically, three distinct groups of practitioners - commonly referred to as sects - emerged in Canada, particularly Ontario, over the course of the nineteenth century: homoeopaths, Thomsonians, and Eclectics. ${ }^{24}$

Practices such as phrenology and hydropathy were also represented, and although their practitioners were less organized, their few publications nonetheless illustrate the controversial nature of pamphlet literature. In 1840, for example, Luke Burke wrote a pamphlet which aimed to convince both advocates and opponents of phrenology (a practice that analyzed cranial bumps to divine character) to reconsider their opinions. In so doing, he presented his own 'improvements' on the 'doctrine,' despite the potential for criticism from phrenologists that his views should have been tested and approved by them before submission to the public. Burke makes clear his reasons for publishing in a lengthy preface: to avoid having his lecture audiences misunderstand or misrepresent his views, while ensuring that they would have something concrete to refresh their memories, 'or to keep alive any degree of ardour [for phrenology] which happened to have been excited. ${ }^{25}$ After countering various objections to his publication, Burke explains that he would either follow up with a 'more direct and minute investigation of the merits of Phrenology,' or wait until further investigation would enable him 'to produce something that may deserve attention. ${ }^{26}$ His pamphlet, therefore, was intended to fill an immediate need in the community.

A pamphlet on another practice, hydrotherapy, expressed the more fervent views of its author on the subject. Robert Hunter, a physician, began his pamphlet entitled Hydrotherapeutics; or, $A$ Treatise on the Water Cure with a matter-of-fact discussion of the 
'water cure,' supported by opinions of European authorities. In contrast to the 'enemies' of hydropathy, Hunter observed: 'We seek not to awaken your passions or to dazzle your understanding - to wound your sensibilities or to flatter your vanity, but we appeal to that reason which is given for the government of your actions. ${ }^{27}$ Nevertheless, not content with appeals to authority and reason, Hunter frequently did appeal to emotion as well. One paragraph from his peroration alone reveals characteristic features of this rhetorical appeal and its use: ${ }^{28}$

\begin{abstract}
And now, I would only remind all who feel themselves involved in this matter, that neither our country nor our country's God will hold those morally guiltless, who either at the shrine of indolent procrastination, or the pompous altar of unbending egotism, dare any longer to officiate in the dire sacrifice of the numbers of our fellow-beings who are marked to appease the rapacity of the pestilential monster - those who either ignorantly or criminally frustrate the attempted rescues of Nature, and then charge her with the fatal results!
\end{abstract}

Such heavy use of italics, exclamation marks and other accentuated typography, a high level of abstraction ('country,' 'God,' 'Nature'), and extended metaphors (human sacrifice) represent, as we shall see, the hallmarks of the more polemical kind of sectarian writing. A later pamphlet on hydropathy published by G.S. De Bonald in Montreal was less shrill overall than Hunter's, but implicitly tended to advertise De Bonald's clinic while presenting the merits of hydropathic treatment. ${ }^{29}$ Despite the promotional overtones, however, both Hunter and De Bonald reflect their orthodox medical training by condemning those who claim universal uses or cures for one form of treatment or who do not acknowledge the merits of other methods. In this way, they try to distance themselves from any appearance of fixation on one idea, no doubt conscious that such fixation was usually the mark of a lay, probably fanatical, writer.

Sectarian authors were more numerous and active in the three main medical sects. As their name implies, the Eclectics adhered to a philosophy of choosing therapeutics from a variety of 'schools' to suit the case at hand; hence, unlike mainstream practitioners, they used homoeopathic remedies, hydropathy, and other so-called 'pathies' - but above all, botanic medicines. Only one extant pamphlet represents Eclecticism, an American-based system, in this country: The People's Guide to Health Prosperity and Good 
Old $\mathrm{Age}^{30}$ this pamphlet, however, is actually an extended advertisement for 'Dr. Kermott's Medicines, ' which were available at the Eclectic Medical Dispensary in London, Ontario. By far the most numerous sectarian pamphlets were written by homoeopaths, a fact not surprising given both their legal status and their larger number in Ontario. Homoeopathy was founded in the late eighteenth century by Samuel Hahnemann, a German physician. Briefly, its main tenets are that like cures like - that is, that medicines causing certain symptoms in a well person should be given to the sick person exhibiting the same symptoms - and that medicines are most efficacious when administered in infinitesimal doses. Both ideas were revolutionary and completely antithetic to mainstream medical practices, which at the time tended to prescribe excessive doses of medicines that then masked the original disease and its symptoms.

Since homoeopathy was so novel in its approaches, many of its practitioners wrote again and again simply to explain them to outsiders. One pamphlet from Stratford, Ontario, Facts and Fallacies about Homoeopathy, may have additionally acted as a pocketsized advertisement for prospective patients. Based on American sources and information, it employs promotional organization, syntax and diction familiar to consumers today: 'It [homoeopathy] is at once precise, effectual, quick, pleasant, safe, and leaves no ill effects. ${ }^{31}$ Two similar homoeopathic pamphlets appeared in Ontario in I860 and I863, respectively: E. Stevenson's Homoeopathy: Its Principles and Practice Explained and Illustrated; and [Dr. Schaefer's] Two Medical Systems Contrasted: Homoeopathy and Alloeopathy. Both follow close on the heels of the 1859 Act legalizing homoeopathy in the province ${ }^{32}$ and may therefore have responded to a need for information in the community. For his pamphlet, Stevenson collated letters he had written to the local Belleville newspaper on the subject; his main desire was not to argue, but 'to impart correct ideas' regarding homoeopathy. After discussing the system's merits and listing countries that recognized homoeopathy together with statistics of its successes, Stevenson concluded by enjoining readers to 'think, think for yourselves. The system courts investigation; - investigate it. There is nothing mysterious about it; it is plain; it is simple; it is truthful.' ${ }^{\prime 33}$ Related homoeopathic pamphlets include two explanatory sheets written by C.E. Jarvis, a homoeopath in London, Ontario; ${ }^{34}$ and two works appearing thirty years earlier that set out to describe the history of homoeopathy, especially as it related to Montreal. ${ }^{35}$ A similar 
publication, R.J. Smith's Lecture on the History of Medicine and the Science of Homeopathy, first appeared in Toronto in 1852 . Unlike other pamphlets, it was revised and reprinted in I857, apparently following Smith's change of address in Toronto; it is therefore likely that Smith too wrote his explanatory pamphlet primarily to publicize his own practice to potential patients. ${ }^{36}$

In all these pamphlets, authors explained the principles of homeopathy and argued for its adoption as a safer, milder, more effective mode of treating illness. Although they occasionally offer high praise for Hahnemann, its founder, ${ }^{37}$ they usually tried hard to adopt a disinterested tone, to convince through reason and evidence rather than through emotional claims of 'cures.' One pamphlet by M.H. Utley, Homeopathy, for the British American Provinces, illustrates this point most clearly. Published in Montreal in I863, the pamphlet not only explained the main tenets of homoeopathy but also provided readers with remedies and directions for their use. In his preface, Utley fully explained his intentions to fill the gaps of domestic medical works while avoiding quackery: he did not aim to make 'accomplished physicians of the public,' but merely to give brief directions for curing conditions for which the physician was typically consulted in Canada. ${ }^{38}$ Like his medical colleagues Hunter and De Bonald, Utley was acutely aware of the line between professional medical claims - even within his own sect - and those of the fanatical amateur. His carefully worded disclaimer about the purpose of his pamphlet sought to differentiate himself as medical author from those who would try to persuade the public by making exaggerated claims for their practice. Moreover, he argued strongly for the value of providing accurate information for domestic use of medicines, for rather than leading to quackery, the 'better the public are informed in regard to the properties and uses of medicines and the principles of their administration, the better they are guarded against quacks and quackery which are already so prevalent.' 39 This stance in writing for the public - that is, to supplement rather than supplant the trained physician - was a common approach in self-help medical publications, including books.

Whereas homoeopaths were the most prolific of sectarian authors, writing numerous pamphlets throughout the nineteenth century, the Thomsonians were unusual in publishing one work, The Unfettered Canadian, throughout the course of one year. Owing to its regular appearance during $I 849$, its consecutive dating, numbering and pagination of issues, its aspirations to become a journal, its funding by subscription, and its inclusion of separate items, this 
publication has usually been classified as a journal. $4^{\circ}$ However, The Unfettered Canadian bears a closer resemblance to pamphlet literature and may therefore be more accurately viewed as a serialized pamphlet.

Like other pamphlets, The Unfettered Canadian began as an immediate reaction to a strong political impetus: the proposed new medical act in Canada West which would have made illegal those medical practitioners known as Thomsonians. Prior to this time, Thomsonians had practised throughout the province, especially among the rural population who preferred accessible, inexpensive domestic treatment. Their system had been established by Samuel Thomson, a New Hampshire farmer, early in the nineteenth century, and it relied on two main treatments: botanical remedies (especially lobelia and cayenne pepper) and steaming. Apparently a reaction to the harsh orthodox medical treatment of the day, Thomson's system called upon Americans to treat both themselves and others in their community by learning the principles of medicine from his books and his agents. In fact, Thomson was a shrewd entrepreneur who made considerable profit from requiring wouldbe healers to purchase a 'right' to practise his system and from suing trespassers of his copyright. Nevertheless, his approaches and his books, New Guide to Health and A Narrative of the Life and Medical Discoveries of Samuel Thomson, garnered a wide following throughout the northeastern United States and into Upper Canada by the $18205 .{ }^{4 \mathrm{I}}$ Of particular significance to Canada was the republican tone of his books, which no doubt attracted followers with liberal leanings.

Analysis of The Unfettered Canadian indicates that its putative editor and almost sole author, Robert Dick, not only had such a political outlook but actively opposed the presumptive powers of any monopolistic organization over the will of the common people. The first issue of his pamphlet made these views abundantly clear, from its unusual title to its detailed exegesis of the proposed medical bill. Basically, The Unfettered Canadian opposed fetters in every sphere of human existence: medical, as well as physical, intellectual, civil or political, religious, or legal fetters. Illustrating this underlying belief were the various, and otherwise disparate, items in the publication - items on the ill effects of tight lacing, alcohol, war, and any related form of tyranny which removes freedom of choice. Dick began his Introduction and Prospectus to the publication, this 'Banner of Liberty and Reform,' by appealing to the 'Freemen of Canada':42 
Can we [Dick always referred to himself in the plural] be pronounced rash or precipitate in sounding the alarm, when we see the chains of an infamous bondage already forged, and waiting only the sanction of Parliament, to entwine, shackle, and gall the limbs of freemen? Can you believe it, Freemen of Canada! that a portion of our M.D's., embodying the selfishness and arrogance of the sect, are laboring indefatigably to urge through the present House of Parliament, a bill of such appalling atrocity ... !

The first of eight aims of his publication, therefore, was to obtain for every man 'the liberty of selecting his own physician ... to carry out his own views of the philosophy and means of health, without subjecting himself, or his assistants, to the slavish dread of a Medical Inquisition. ${ }^{\prime 43}$ More importantly, Dick's seventh aim was 'To advocate, and promote, social, intellectual and moral Reforms in general'; and he concluded his introduction by suggesting The Unfettered Canadian would hold up to 'universal execration, the loathsome fetters of ignorance, of arrogance, of error and of vice.'44

To convey the combined messages of freedom and toleration to readers, Dick often wrote colourfully, evidently drawing on his experience both as Baptist preacher and as teacher (at the Brockville Academy). ${ }^{45} \mathrm{He}$ either fumed and railed against social injustices, including a potential medical monopoly, himself, or he simply reprinted items supporting his overall theme of social reform or praising the Thomsonian system of medicine. When the proposed bill fuelling Dick's indignation did not become law, The Unfettered Canadian stopped appearing. Born of one kind of necessity, it may have died owing to different needs - money and the sustenance gained through adversity. Moreover, the closing pages of its last issue presented the constitution of the Canadian Eclectic Medical Society, thus heralding a new direction for Thomsonians in the province as they aligned themselves with the reformed set of trained medical practitioners, the Eclectics. With these changes, Dick's reasons for writing or continuing his publication no longer existed. ${ }^{46}$

Despite the fact that it appeared at regular intervals, The Unfettered Canadian bears all the marks of a typical pamphlet: written primarily by one man, it was a highly polemical publication, triggered by impending legislation, which unilaterally attacked a group of individuals and an ideological system - those trained, elite medical practitioners who sought to monopolize medicine for their own gains. When the subject was no longer relevant or timely 
because of changed political and professional circumstances, Dick stopped writing the pamphlet and moved on to other concerns. ${ }^{47}$ Supporting this view is the fact that the Thomsonians themselves had resolved only the year before to publish a pamphlet for the public and members of the legislature; moreover, Dick himself explained the publishing situation clearly: 48

We frequently receive orders for our little pioneer, from individuals who state that it has just fallen into their hands ... many of whom will unquestionably feel that they ought to have been apprised of our first movement, if not consulted in relation thereto. In palliation of whatever neglect we may be chargeable with, we beg to state that our late "eleventh hour" discovery of the dark designs of our Monopoly Drs. against our liberty and rights, left us no time for corresponce [sic] or consultation! The work was first thought of on the one day, and commenced on the next with an energy which enabled us to send a flood of the first number into both Houses of Parliament, before the medical inquisition bill had reached its second reading, which was carried by a majority of one solitary vote!!! In producing this feeble majority the Unfettered Canadian is entitled, perhaps, to a share of the credit.

Thus, in the same way that medical authors responded to a social crisis like disease, they also reacted to political and related professional crises by producing pamphlets for immediate distribution. Mostly advocates of specific medical sects, authors were generally individualistic in their approaches and remained so - unlike the situation with disease pamphlets, where corporate authorship became the norm by the twentieth century. This is not surprising, given that corporate authorship usually meant the government, a conservative institution that would have no direct interest in entering the arena of competing medical systems. Of any pamphlet literature, it might be argued that The Unfettered Canadian represented a corporate voice, that of the Thomsonian Medical Reform Association, by citing the publication of meeting minutes and constitution in its pages. Certainly providing this information would have been a service to readers as it furthered the Thomsonian cause in Canada. However, apart from letters to the editor, the publication reflects entirely the idiosyncratic, polemical thinking and writing of its conductor, Robert Dick, to a degree not normally found in corporately produced pamphlets.

A strong indicator of polemics in authorship, of course, is the use 
of dramatic typography for emphasis (italics, dashes, bold type, multiple exclamation marks, etc.), high levels of abstraction and extended metaphors - all employed extensively by Robert Dick. Dick's style, in fact, closely resembles that of other lay authors who later deeply opposed vaccination: his 'chains of an infamous bondage' and 'slavish dread of a Medical Inquisition' anticipates David Edwards's 'enslavement' from which 'the People demand deliverance.' Professionally trained medical authors, however, typically included disclaimers about the applicability of their system for all ailments or about their purpose in writing for the public - as did Utley, Hunter and De Bonald. Indeed, even though Robert Hunter adopted some of the techniques of more polemical authors to persuade his readership about the merits of hydropathy, he stopped short of attacking all his colleagues in the medical profession. Dick, on the other hand, had no such sense of collegiality to maintain since he was not medically trained.

Like those who wrote on disease, authors of sectarian pamphlets generally wrote for the public, either identifying their intended readership clearly in their titles (an anonymous Eclectic author's 'People's Guide to Health'; Utley's 'plain practical work, adapted to ... all intelligent minds') or providing an abstract of the whole work in their title:

Hydrotherapeutics; or, A Treatise on the Water Cure; Being a Digest of the Opinions and Experience of Some of the Most Distinguished Physicians in Europe and America, on the Curative Virtues of Water. To Which Are Added the Voluntary Acknowledgments of a Few Influential Patients, in Gratitude for Benefit Derived from Its Use, When Every Other Means Had Failed. Also, Some Practical Remarks on Typhus, Ship or Emigrant Fever, as It Occurred in This Province; with Observations on the Best Means of Prevention and Cure.

(As with disease pamphlets too, such abstracts tended to appear in the first half of the nineteenth century, continuing what had been a centuries-old publishing practice.) At least one writer (Utley), however, suggested that his self-help advice was for people in inaccessible areas who should defer to the expertise of the trained physician under normal circumstances.

Finally, authorship in general extended to multiple, consecutive productions of related pamphlets, which may therefore conveniently be called serialized pamphlets. Robert Dick's The Unfet- 
tered Canadian, despite the external trappings of a journal, functions internally as a pamphlet - provoking and inciting its readers to action, berating and exposing its antagonists to ridicule. Acting as a defender of freedom and toleration in the province, Dick could lay down his arms once the pressing political crisis blew over.

Another pamphlet that similarly appeared regularly under the authorship of one man was David Edwards's Medical Criticism. Although not paginated consecutively, this work came out weekly between 1882 and I 883 . Edwards, like Dick, had an axe to grind with the monopolistic impulses of the medical profession: 49

are the honorable members [of Parliament] who have combined to extend this right to the Allopathic [mainstream] practitioners of Ontario, better qualified to decide on the merit of the Allopaths' claims than would be the same number of washerwomen? Barring that interesting group of eleven members of the medical profession, who have contrived to secure seats for the sole purpose of guarding the unsuspecting public against medical heresy, we should prefer the combined wisdom of a corresponding number of washerwomen; the ladies of the tub would, in many instances, remember how their mothers and grandmothers used to cure all the ills that flesh is heir to, by the aid of a few herbs, or that of a bucket of hot water and a blanket; these discriminating individuals would therefore if any M.D. dared to present himself at the bar of their house, and undertake to tell them the Latin name of their every muscle, and the number of their bones - probably serve such a false staff as the merry wives of Windsor served theirs, - ruthlessly plunge him into the nearest tub.

Edwards's main purpose in writing Medical Criticism, therefore, was to present 'alternative modes of treatment, from which the judicious public may divine to some extent, in what manner they may expect to be treated, under certain circumstances, on sending for a doctor of this or that particular school.' Later issues briefly discussed the self-help medicine of John Wesley, hydropathy, homoeopathy, ${ }^{\circ}$ and so-called allopathy - which has 'no definite principle to present to us, but in lieu of that, they have an Act of Parliament. ${ }^{\prime 51}$ As noted earlier, Edwards also exploited this opportunity to expound on the issue of vaccination. For both issues, he employed the rhetorical tone and language of the oppressed, echoing Dick's writing some thirty years earlier: ${ }^{22}$ 
History notoriously repeats itself, and it is obvious that the "liberal and enlightened" Legislature of Ontario took a leaf out of the history of Spain, when it instituted the Medical Inquisition; it is a happy circumstance that the Inquisitors have substituted the pocket-screw for the thumbscrew and the rack...

In short, Medical Criticism, like The Unfettered Canadian before it, signifies a pamphlet-writing campaign - a flood of pamphlets, to use Dick's expression - by one man to raise the alarm and effect change in public opinion with respect to mainstream medicine. ${ }^{53}$

Regardless of their form, Canadian medical pamphlets up to the twentieth century focus on two main themes, disease and sectarian medicine. Often written by medical practitioners, they were obviously recognized as appropriate channels for communicating medical information to the public. All pamphlet authors clearly understood this role to the extent that they adopted appropriate levels of language and forms of argument to convey their message most meaningfully to their lay audience. Of course, in some cases pamphlets were used more for promotional than informational purposes; nevertheless, almost all pamphlets used persuasive style together with typographical techniques to capture readers' attention and maintain their interest. Moreover, the more persuasive the intention, the more overt the appeals to emotion and truth. Since they were not their own printers, however, authors had to rely on others to produce their pamphlets: it was local printers who provided a vital link in the communicating of their medical ideas.

From the beginning, medical pamphlets were printed in Canadian newspaper offices (or their job-printing 'subsidiary'). Two main reasons for this situation exist: first, the authors would have paid to have their work printed, and thus chose a handy printer to do the job; and second, the logical choice was the press associated with the local newspaper in towns where only this one press could operate profitably. The rise of the newspaper in Canada during the nineteenth century meant that more towns had active printing presses that could be used to print other items for local use announcements, advertisements, petitions, and other ephemera. ${ }^{54}$

Since they often advertised their job printing services to the community, ${ }^{55}$ it is clear that printers saw these activities as a purely commercial endeavour. It would thus be inappropriate to attribute any motive or interest in publishing pamphlet literature to them beyond immediate financial gain. This was not necessarily true of books, however, for printers themselves undertook to publish Cana- 
dian editions of medical books for a variety of reasons, including social or political ones. ${ }^{56}$ So far there is no evidence to suggest that Canadian physicians themselves acted as printers for their medical works, even though some did own or operate newspapers. ${ }^{57}$ In some respects, however, physician-authors of pamphlets may be seen as fulfilling the role of publisher as well, since they hired a printer and underwrote the cost of production. This role expanded first with the operation of serialized pamphlets like The Unfettered Canadian, and then extended to the running of Canadian medical journals by physician-publishers. ${ }^{58}$

From the beginning too, pamphlet publication was supported directly or indirectly by the government. For example, the Quebec government paid for Direction pour la guérison du Mal de la Baie St-Paul, although it had been commissioned by James Bowman, in 1785. ${ }^{59}$ The federal government issued the Memorandum on Cholera in 1866; and by 1924, when Heagerty's Small-Pox and Vaccination treatise appeared, the government was the only publisher to produce medical pamphlets routinely.$^{60}$ This trend illustrates both the decline in pamphlet-writing activity by independent physicianauthors owing to the professionalization of medicine (which frowned heavily on writing for the public) and the increasing involvement of the state in all spheres of Canadian life.

Given their ephemeral nature and the lack of extensive publishing records in Canada before the twentieth century, it is difficult to comment upon the production process within the printing shop itself, and even less information exists for the size of the print run. Similarly, the somewhat intangible relationship between author and printer cannot be explored; unlike books, discrete pamphlets are too brief and pointed even to allow much room for the author's observations on this feature of publishing. But in serialized form, there is space for authorial comment, and so it is not surprising that both David Edwards and Robert Dick would mention their printers. On the whole, however, their comments merely address delays in publishing caused by changes in printers, ${ }^{6 \mathrm{I}}$ although Dick did briefly outline his method of paying his printer one issue behind. ${ }^{62}$ Information about the distribution of medical pamphlets remains even more sketchy. Three main avenues operated: distribution by the author himself, stationery and newspaper offices, and mail. Cl. T. Campbell, for instance, may have handed his little pamphlet to patients, since it not only explained the basic tenets of his form of medical practice, but also provided the location of his office 'Over Hoffman's Store, Lynch's Block, Stratford, Ont.' Similarly, Robert 
Dick likely distributed copies of The Unfettered Canadian in his lecture swing through the countryside during the summer of I 849; and the Conseil Provincial d'Hygiène provided free copies of its cholera pamphlet upon request. ${ }^{63}$ Pamphlets were usually sold at the office of the newspaper responsible for printing them, however, as Edwards indicated in his series. Some were at first sold by prior subscription - that is, to people who agreed to buy a copy once the pamphlet was printed - and as Marie Tremaine has noted, thirtythree subscribers appear on Robert Jones's pamphlet on the Mal de la Baie St-Paul, comprising mostly Montreal merchants and only one physician. ${ }^{64}$

Subscription was necessary for serialized pamphlets, of course, to ensure their continuation, and the preferred method of distributing them on an ongoing basis was the mail. The Unfettered Canadian provides detailed information about these features of distribution. Indeed, its creator, Robert Dick, was keenly aware of the need for subscriptions to sustain his publication; to encourage their growth, he developed a network of agents and other innovative methods of distributing the pamphlet. ${ }^{65} \mathrm{He}$ even introduced a new method of payment for subscribers, whom he was anxious to keep 'in good humour with themselves and us.' Dick felt that serial publications should not complain about their patrons, and he recognized that 'men of business' had weightier matters to think about with time passing too quickly to remember their 'trifling obligations.' Since 'the trouble of writing, folding and addressing a letter is very great,' Dick gave his subscribers an addressed envelope for submitting money, names of new subscribers, or articles. The envelope evidently identified items to help the sender expedite the submission. ${ }^{66} \mathrm{His}$ attempts to find workable solutions to distributing items by mail and keeping track of payments later reached fruition in the I 850 , when Dick invented an addressing machine which fixed thousands of prepared labels in an hour while acting simultaneously as a subscription ledger. Once patented, Dick's device eventually made him wealthy as hundreds of North American newspapers and journals adopted it (including the Toronto Globe and Leader). ${ }^{67}$

Producing and distributing medical pamphlets in Canada thus involved a number of other people from printers to postal workers. For the most part, the pamphlets were probably viewed simply as commodities by others in the publishing trade. Only one trend emerged in the publication of medical pamphlets between the eighteenth and twentieth centuries: the decreased number of independent authors in favour of government sponsorship by the I 920 . 
As the government played a larger role in public health by the end of the nineteenth century, ${ }^{68}$ it took over the task of conveying information for the public good in easily handled and read pamphlets. Not only did such brief publications suit the government's purpose nicely, but they also retained the general size and format used in earlier works by independent authors. Indeed, a popularly called 'Blue Books' series issued by the Department of Health to Canadian homemakers throughout the I920s and I930s maintained a tradition of covering pamphlets in blue paper that dated back not only to printer William Brown's production of Direction pour la guérison du Mal de la Baie St-Paul in 1785 but also beyond to eighteenth-century Europe. ${ }^{69}$

The medical pamphlet in Canada thus represented a distinct genre of medical literature whose function differed from other publications. In short, pamphlets were brief documents intended for general readership and offering one author's views in response to a specific, topical stimulus. Consequently, they appear wherever local action is needed: in disease-plagued Baie St-Paul or Montreal; in politically controlled Ontario or British Columbia; and in medically monopolized Ontario. Authors attempted to reach their intended audience through their titles, which either abstracted the work or identified those who would find it useful. Once the immediate stimulus disappeared, so too did the pamphlets and their otherwise low-profile authors. This ephemeral quality becomes most noticeable with serialized pamphlets: representing a sustained pamphlet campaign by one author, they naturally wound down once the original crisis had passed. The fact that pamphlets could be serialized also highlights another point worth emphasizing: although ephemeral and brief by definition, medical pamphlets could vary in form and length. Defining pamphlets narrowly by the number of pages instead of by their purpose, style and function would exclude the works of such authors as Stimson, Utley, and Hunter. Such exclusion would mean that, with their small size and focused, functional nature, these works would fare poorly in comparison with book-length treatises having unity of theme and often high-quality literary style. Viewed as pamphlets, their value emerges as communications having immediate relevance for the time and place for which they were intended.

Pamphlets were obviously the easiest medical works to prepare indigenously in the early years of Canadian settlement, using the printing presses of local newspapers. Significantly, they began 
appearing in the eighteenth century during times of social crisis, when timeliness dictated expedient production of small, informational documents for wide distribution. Disease provided the initial impetus for their appearance, as it had in the United States several decades earlier. ${ }^{70}$ In Canada, unlike the United States where early authors were primarily clergy, it was the government that took the most active role in sponsoring and authoring pamphlets up to the twentieth century. In keeping with pamphlet literature in general, even those dealing with disease proferred competing theories about its origin, transmission method, and prevention or treatment.

Beginning in the I840s, pamphlet authors reacted to specific issues within the practice of medicine itself, notably in advocating certain systems of treatment. Their pamphlets in particular were often more adversarial than informational; to borrow Yves Avril's expression, they unilaterally attacked a group of individuals (usually monopolistic mainstream medical practitioners) or an ideological system (orthodox medical practice). The style of writing employed by the more extreme of the lay authors therefore offers much fodder for rhetorical analysis of the language of oppression. The style of professionally trained authors, on the other hand, is more deliberative; providing measured discussion of the merits of one system such as homoeopathy over another, these practitioners appealed to authority rather than emotion. Moreover, as medical practitioners themselves, these authors reveal a sense of collegiality and professionalism in their disclaimers about universal application of their system, about explaining medical approaches to the public, and about providing advice for domestic medicine only where the trained physician is not available. Although they were sectarian, they reflect the larger concerns of the medical profession as a whole, for similar disclaimers were written in pamphlets on disease, and later in self-help medical books. By the end of the nineteenth century, professionalization of medicine had evolved and sectarian medicine declined to such an extent that independent medical practitioners perceived writing pamphlets for the public, and paying for their printing, as a form of self-promotion - ultimately, an unprofessional act. Writing such pamphlets under the auspices of a corporate entity, such as the government, became for them a more respectable form of authorship since it provided a needed buffer and hence an air of objectivity - between themselves and their patients, whom they no longer had to solicit for business.

In sum, their topicality, persuasive or informational intent, ease of production and distribution, and relatively inexpensive nature, 
ensured that medical pamphlets remained a separate medium of communication in this country from the eighteenth to twentieth centuries. Those discussed here effectively highlight trends in their publication, even though they remain merely examples from pamphlets that have survived. More importantly, they demonstrate that the pamphleteering tradition played an active role in the development of Canadian medicine, a role that may have tempered views already held by readers, if not influencing medical legislation directly.

\section{RÉSUMÉ}

On n'a encore mené aucune étude générique des pamphlets médicaux, bien qu'ils forment le plus ancien type de documentation médicale publiée au Canada. Une approche rhétorique révèle des similitudes quant aux intentions de leurs auteurs et aux circonstances de publication. Cette approche sert à élargir notre compréhension de ce genre de publication et de l'art du pamphlétaire, car elle permet l'inclusion, sous le terme «pamphlet», de quelques publications en série et d'oeuvres monographiques de peu d'ampleur. La mise en relief des différences entre ces pamphlets et les autres types de documentation médicale permet de dégager leur rôle particulier dans l'histoire médicale du Canada. Quel qu'aitété leur format, les pamphlets médicaux faisaient écho à des incitations politiques, sociales et autres, dans le but d'orienter leurs lecteurs vers un comportement bien défini. 


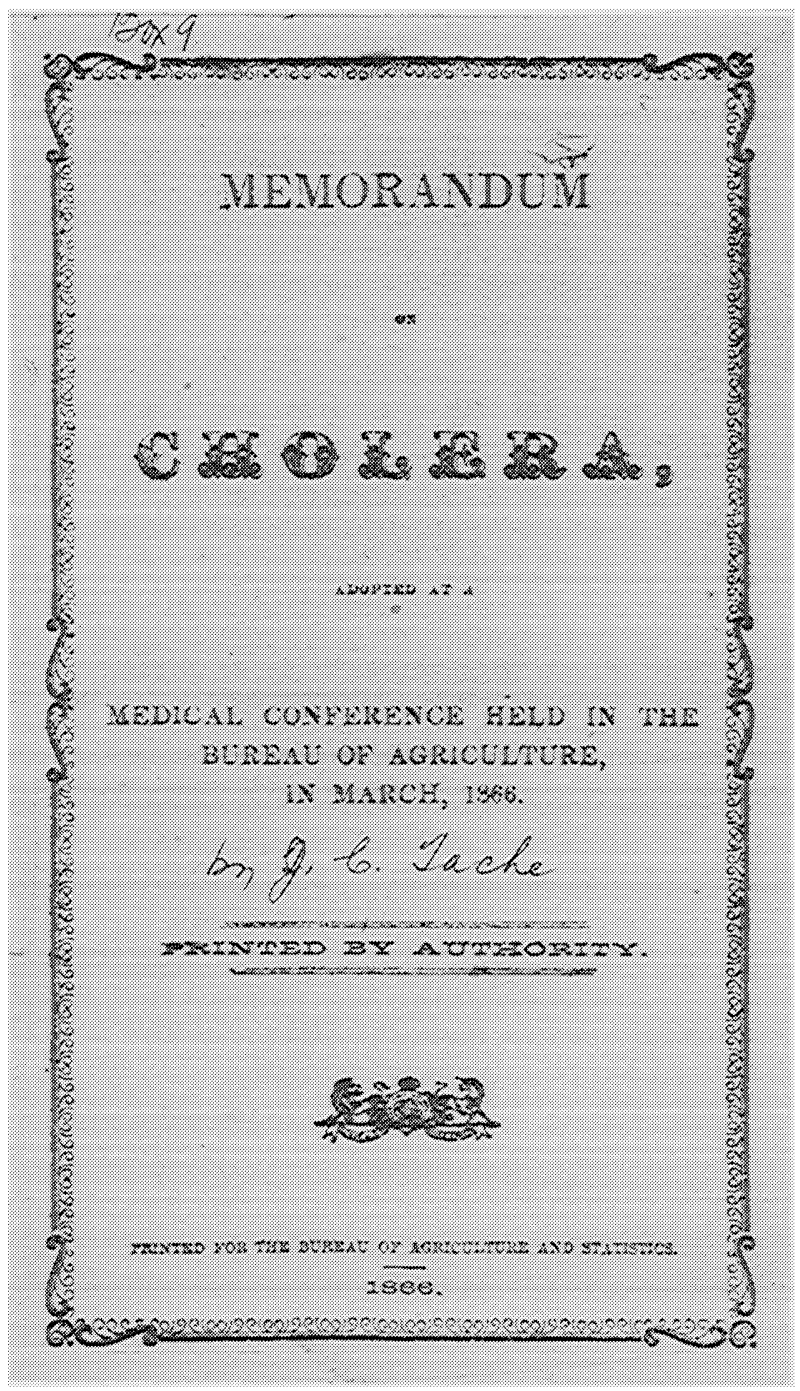

I and 2. An example of government sponsorship of disease pamphlets, the Memorandum on Cholera was first published in English and French versions in 1866.

Fig. I From the Crane Collection, Department of History of Medicine, University of Western Ontario, London, Ontario.

Fig. 2 From author's personal collection. 


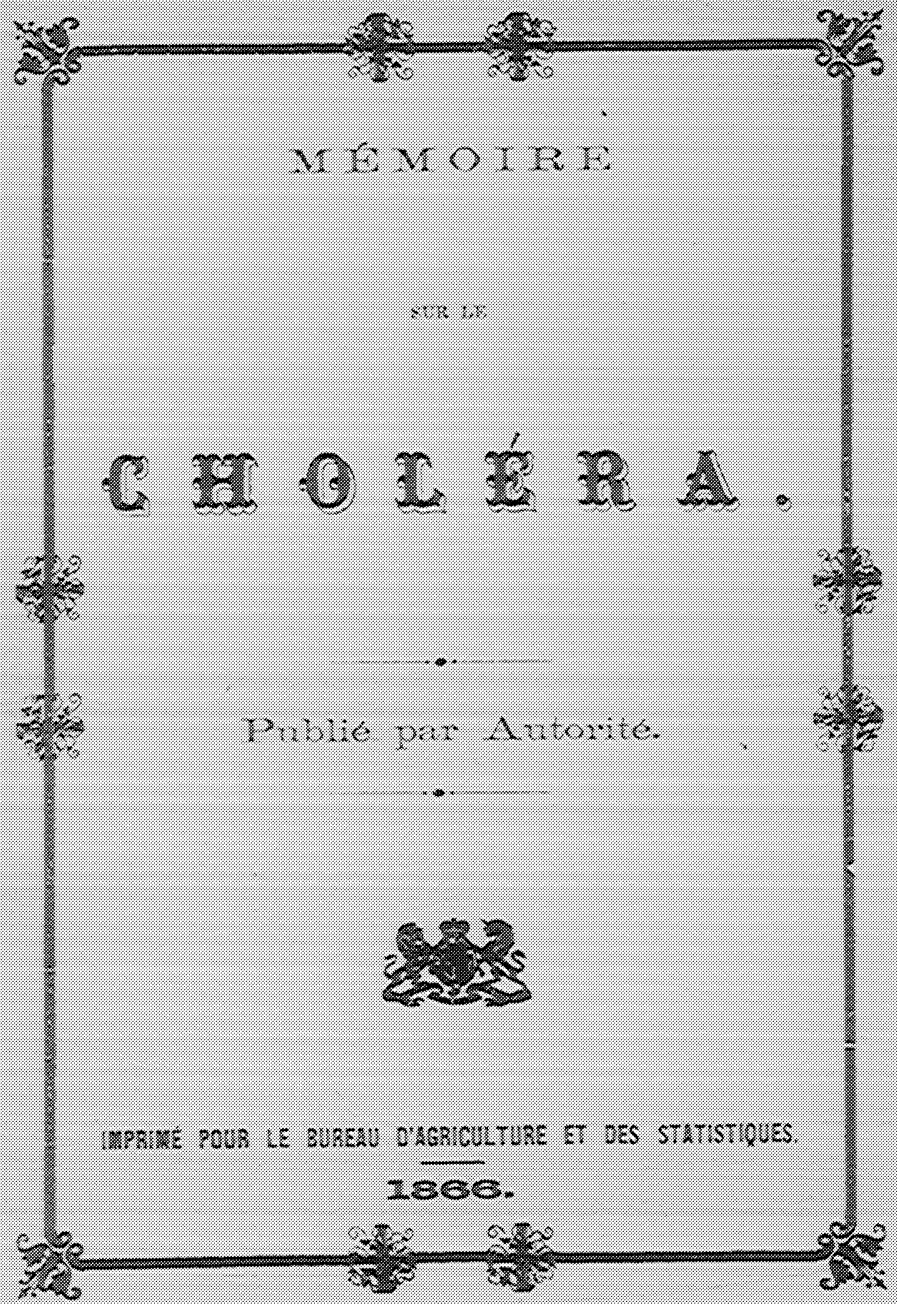


Es sent on approval.

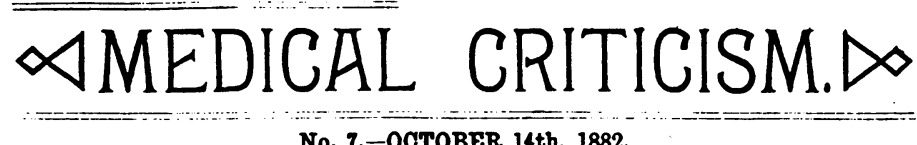

No. 7.-OCTOBER 14th, 1882. A Weekly Sheet, by David EDwards, published on Saturday, and sold at Hawkins E Co.'s,
67 Yonge Street, Toronto.

PRICE 50 CENTS-Copies or any single number can be had, in quantities. ut 15c. per dozen.

It cost the Province of Ontario $\$ 28,500$ to bring emigrants from Europe in 1881 ; even on the low ground of economy therefore, it behoves the Legislature to consider if more efficacious means cannot be adopted for preserving and protectung the lives ze have. "Prevention" of loss would surely be preferable to the "cure" of immigration.

\section{"DEATH THROUGH VACCINATION."}

Although such a record as that above written is "graven with an iron pen" in the heart of many a weeping mother. we may search those delusive documents, the death registers of the world in vain, in quest of any such truthful averment.

Which weapon has slain the more-the sword or the lancet?

The Provincial Board of Health has issued a circular to the clerks of Municipalities, enquiring if the Municipalities are exercising the powers vested in them for the preservation of the public health; the imagination of the Board, one would suppose to have been in a healthy condition when they issued this circular on the assumption that any paid clerk would inform against his paymasters.

A dying man in the Toronto Hospital is related to have craved for water; the response on the part of the nurse, took the form of hustling the screens around him, with the remark-" he's got to die anyhow," and he would have died without water being procured for him but for the intervention of the lady who supplied this information. The writer, in publishing this circumstance, would be sorry to cast any aspersion on the management of the hospital, on that account, but it has impressed him with the necessity of all persons, who aspire to tend the sick, being phrenologically examined before being permitted so to do. It is undeniable that many men enter the medical profession from mere mercenary motives; such men will purr about the wealthy to an unlimited extent, and tyrannize over the poor, especially in hospitals. The foregoing observations are made in the consciousness that there are physicians in this city, so ignorant as to deny the facts of phrenological science ; if such persons have not been present when a man, in a mesmeric sleep has res-

3. Although published sequentially, David Edwards's Medical Criticism acted functionally as a pamphlet. Intended to examine different approaches to medical practice, it quickly took up the anti-vaccination cause. From a copy bound with Edwards's related pamphlets, Pulpit Criticism, at the D.B. Weldon Library, University of Western Ontario, London, Ontario. 


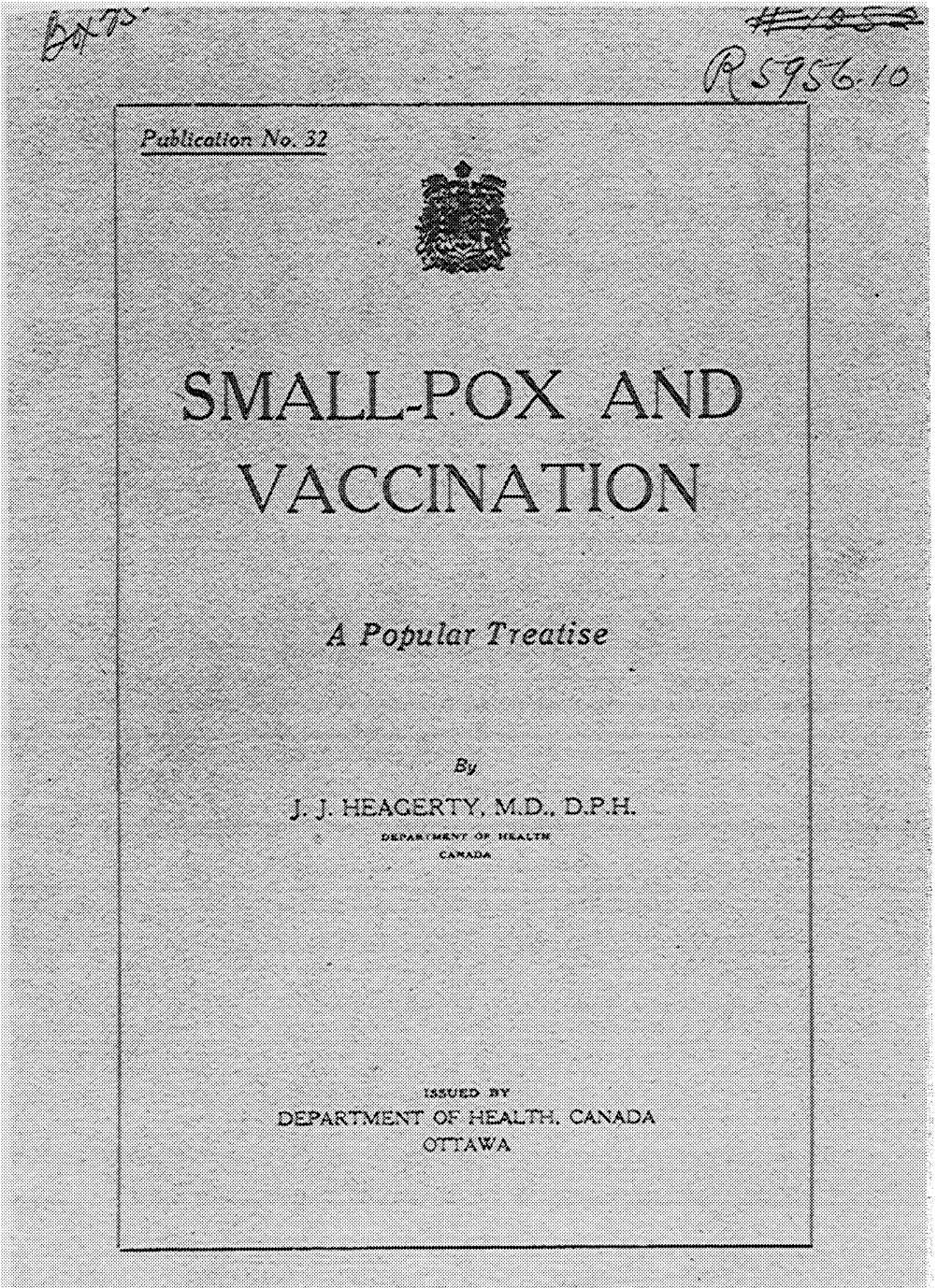

4. By the twentieth century, Canadian medical authors such as J.J. Heagerty typically signed pamphlets not as individuals but as representatives of corporate or government agencies. From the Crane Collection, Department of History of Medicine, University of Western Ontario, London, Ontario. 


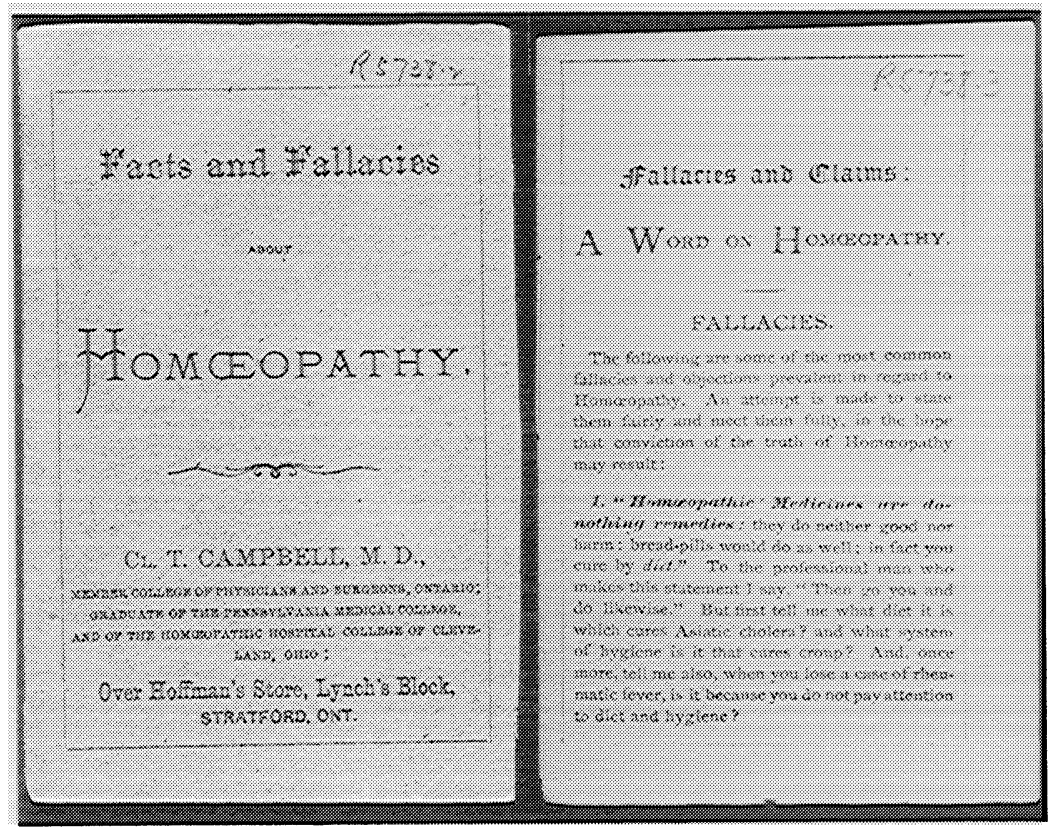

5. Representatives of medical sects such as homoeopathy published pamphlets to explain their form of medical practice to the general public. Internal evidence suggests that $\mathrm{Cl}$. T. Campbell's small pamphlet, shown here in bound and unbound copies, was an American publication to which Campbell added wrappers showing his credentials and location. From the Crane Collection, Department of History of Medicine, University of Western Ontario, London, Ontario. 


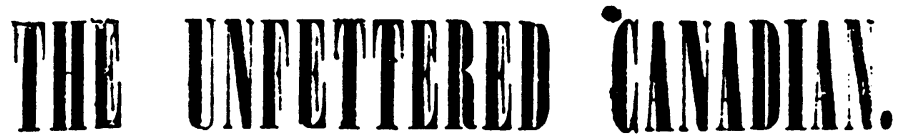

Vol. 1. Brockville, Jan. 1849. No. 1.

PRotosed MeDical inquisiTroN.

That none may be able to charge us with presenting a garbled statement of the "Proposed Act"of Incorporation of the Medical Practitioners of Upper Canada," we have determined to publish the whole as follows; appending such notes as we deem necessary.

\section{AN ACT.}

To incorporate the Members of the Medioal ProJeation in Upper Canada, and to regulate the Study and Practioe of Phyric and Surgery therein.

28th July, 1847.

Whrezas the lawa now in force in Upper Canadn, for regulating the Practice of Medicine, Surgery and Midwifery, require amendment ' And whereas it is higlly' desirable that the Medical Profesajion of Upper Cinada (see note 1.)

\section{NOTES.}

1. We have examined this bill carefully throughout, and find that all, and nrery one of its provisions, are for the uspecial benefit of one sect only of the Medical Profession! the egotistical arrogance of which, shines conspicuousty in its claiming to be "The Medical Profession of Canada!" Now, while aforesaid be placed on a more respectable and c: ficient footung, and that better mcans shintili $t$. provided for the conviction and puniemeat (?2.) : .

we yield to no man in our admiratic: of whatever is excellent or good in tlis? principles of this sect, or in the chararters of its indiridual members, we can. not cease to be astonished at the amnzing blindness of the supporters of this: bill. Do they not see the storm and tempest of a rightcous popular indir. nation, which is now bearing away with the irresistible grasp of the whiri. wiud, the rashily assumed claims of THE Church, which aimed at giring ecclesiastical law to Canada? Surcly they do not see it, or the equally obnoxions claims of this bill, had never been promulgated at this crisis.

2. This is the very marrow of th: bill! Oh! how its authors thrsst fo. the disinterested (?) privilege of heaping fires, costs and IMPRISONME. ITS on every man, or woman, who, dares to administer medical relief to suffiring humanity, without first running to ask?

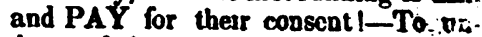
derstand the mcans of conviction and the nature of the punishments sught,

\section{Robert Dick's serialized publication, The Unfettered}

Canadian, bore all the hallmarks of pamphlet literature. Apart from microfilm copies in Canada, the original is known to exist only at the National Library of Medicine, Bethesda, Maryland. 
NOTES

I Earlier medical works about Canada had appeared in Europe. For example, William Vaughan, The Newlanders Cure (London: Imprinted by N.O. for F. Constable, I630); and Soeur Jeanne Françoise Jucherau, Histoire de l'HôtelDieu de Québec (Montauban: Chez Jerosme Legier, I75 I).

2 Aegidius Fauteux, The Introduction of Printing into Canada: A Brief History (Montreal: Rolland Paper, I930), 42-45, 71; H. Pearson Gundy, Early Printers and Printing in the Canadas (Toronto: Bibliographical Society of Canada, 1964), 2-3; and George Parker, The Beginnings of the Book Trade in Canada (Toronto: University of Toronto Press, 1985), 27, 35.

3 Craig E. Harline, Pamphlets, Printing, and Political Culture in the Early Dutch Republic (Dordrecht: Martinus Nijhoff, 1987), 3.

4 Yves Avril, 'Le pamphlet: essai de définition et analyse de quelques-uns de ses procédés,' Etudes littéraires I I (1978): 265-8 I (at 265). See also other articles in this special issue, particularly Marc Angenot, 'La parole pamphlétaire,' 255-64 (especially 262-4); and Georges Vignoux, 'L'argumentation pamphlétaire: effets de sens, effets de pouvoir,' 283-97 (especially 283-85).

5 Encyclopedia Britannica, 9th ed., I888, s.v. Pamphlet.

6 All of these printed forms of information were published in Canada during the nineteenth century, and although they are not considered here, it is worth remembering that they (particularly offprints) did provide other channels for disseminating medical information. For brief consideration of these forms and their discussion in Canada, see Jennifer J. Connor, 'To Advocate, to Diffuse, and to Elevate: The Culture and Context of Medical Publishing in Canada, 1630 to I920' (Ph.D. diss., The University of Western Ontario, I992), 89-9I, n. 6-8.

7 Direction pour la guérison du mal de la Baie St-Paul (Québec: Chez Guillaume Brown, 1785) (сінм/гсмн No. 55035), [3], 15, 16; and Robert Jones, Remarks on the Distemper Generally Known by the Name of the Molbay Disease, Including a Description of Its Symptoms and Method of Cure Chiefly Intended for the Use of the Clerical and Other Gentlemen Residing in the Country (Montreal: Printed by Fleury Mesplet, 1786) (СІнм/ICMH No. 20682).

For this discussion, original editions were examined whenever possible, together with their issue in microfiche form by the Canadian Institute for Historical Microreproductions. The СІнм/Iсмн number is provided where applicable.

8 For example, [J.C. Taché], Memorandum on Cholera, Adopted at a Medical Conference Held in the Bureau of Agriculture, in March, I866 ([Ottawa]: Printed for the Bureau of Agriculture and Statistics, I866) (сінм/І Ісмн No. 34369 |, Mémoire sur le choléra ([Ottawa]: Imprimé pour Le Bureau d'agriculture et des statistiques, I 866) (СІнм/Ісмн No. 34368); Memorandum on Cholera, Adopted at a Medical Conference Held in the Bureau of Agriculture, in March, I 866 (Printed for the Bureau of Agriculture and Statistics, I 873) (ciHm/ Iсмн No. 47058); J.I. Desroches, Choléra: Le choléra, le régime sanitaire du pays, mesures d'hygiène individuelle destinées à préserver du chodéra [sic] - L'hygiène municipale. - Assistance publique, l'hygiène et les senti- 
ments familiaux (s.1.: s.n., [1885 ?])/Сıнm/ICMH No. 63036); Conseil Provincial d'Hygiène (Province de Québec), Le choléra, comment le prévenir et le combattre: conseils pratiques aux familles (s.l.: s.n., [18- ?])/сгнм/Ісмн No. o1775); and Dr. Roome, Memorandum on Cholera As to Its Origin, Organism, Causes and Prevention with Premonitory Symptoms (Ottawa: Printed by order of the Minister of Agriculture, I 893) (Сінм/Ісмн No. 53963).

9 Elam Stimson, The Cholera Beacon: Being a Treatise on the Epidemic Cholera As It Appeared in Upper Canada, in I832-4, with a Plain and Practical Description of the First Grade, or Premonitory Symptoms, and the Various Forms of Attack, by Which the Disease May Be Detected in Its Curable State; Together with Directions for Successful Treatment. Designed for Popular Instruction (Dundas: Printed by G.H. Hackstaff, I835)/CIHM/ICMH No. 63184).

Io Cholera: Whence It Comes, What It Is, How It Begins, What Causes It, How to Cure It, How to Prevent It, How to Make the Best of It. A Popular Lecture. By an M.D. Also, Four Other Modes of Cure, by eminent medical authorities (Toronto: Printed for the author by Robertson \& Cook, Printers and Publishers, I867) (Сінм/Ісмн No. 53947), Pamphlet I867 No. 23, Archives of Ontario (hereafter referred to as $\mathrm{AO}$ ).

I I See, for example, R.J. Morris, 'Religion and Medicine: The Cholera Pamphlets of Oxford, I832, I 849 and I854,' Medical History I9 (I975): 256-70.

I2 J.A. Crevier, Le choléra: Son historique, son origine, sa nature, les causes qui le produisent, ainsi que celles des autres maladies épidémiques ou contagieuses produites par les microbes, ses symptômes, son traitement, les soins hygiéniques et médicaux pour s'en préserver et éviter aussi les autres maladies contagieuses (Montréal: Imprimerie Générale, I885) (Сінм/ICMH No. 04190).

I3 J. Emery-Coderre, Vaccination: étude sur les effets de la vaccination (Montréal: Des presses à vapeur de 'la Minerve,' I 875) (Сінм/ICMH No. OІ660).

I4 David Edwards, 'Testimony Relating to Vaccination,' Medical Criticism, 7 October $1882,2$.

I5 'Vaccination,' Medical Criticism, 28 October I882, 2.

I6 'Vaccination,' Medical Criticism, 25 November I882, 2.

17 'Vaccination,' Medical Criticism, 9 December I882, 2.

I8 Michael Bliss, Plague: A Story of Smallpox in Montreal (Toronto: HarperCollins, I99I), especially chapter 8 .

I9 William H. Hingston, Remarks on Vaccination (Montreal: Perrault Printing Company, I885) (СІнм/Ісмн No. or 570); Remarques sur la vaccination (Montréal: Perrault, I885), I5, (Сінм/ICMH No. OI 57 I).

20 Paul Adolphus Bator, 'The Health Reformers versus the Common Canadian: The Controversy Over Compulsory Vaccination Against Smallpox in Toronto and Ontario, 1900-1920,' Ontario History 75 (1983): 348-73; Katherine Arnup, " "Victims of Vaccination"?: Opposition to Compulsory Immunization in Ontario, 1900-90,' Canadian Bulletin of Medical History 9 (1992): 159-76. See also Barbara Lazenby Craig, 'State Medicine in Transition: Battling Smallpox in Ontario, I882-1885,' Ontario History 75 (1983): 318-47. 
2 I Charles A. Hodgetts, A Descriptive Article on Smallpox with 20 Illustrations (Toronto: Printed and published by L.K. Cameron, I905), Pamphlet I 905 No. 37, AO.

22 J.J. Heagerty, Small-Pox and Vaccination: A Popular Treatise (Ottawa: Department of Health, 1924), box 25, J.W. Crane Collection, Department of History of Medicine, University of Western Ontario, London, Ontario (hereafter referred to as Crane Collection).

23 The Alarm, Official Bulletin of the Anti-Vaccination League and Medical Freedom League of B.C., Vol. I, No. I, 27 March 1925, Pamphlet 1925-54, City of Vancouver Archives.

24 For full discussion of sectarian medicine in Ontario, see J.T.H. Connor, 'Minority Medicine in Ontario, 1795 to I903: A Study of Medical Pluralism and Its Decline,' (Ph.D. diss., University of Waterloo, I989). See also J.T.H. Connor, ' "A sort of felo-de-se $e^{\prime \prime}$ : Eclecticism, Related Medical Sects and Their Decline in Victorian Ontario,' Bulletin of the History of Medicine 65 (r 991 ): 503-27.

25 Luke Burke, Phrenological Enquiries, Parts I \& II, Being an Investigation First of the Causes Which Have Prevented the General Reception of Phrenology, Secondly, of the Nature and Advantages of the Researches of Its Advocates, and Elucidating the Imperfections of the 'Present System,' and the Improvements and Discoveries of the Author (Quebec: W. Cowan \& Son, I 840 ), v, (СIHм/ICMH No. 52642).

26 Ibid., xv. Phrenological pamphlets appeared later in the century, mainly to defend or advertise particular practitioners. See, for example, F.J.L. Cavanagh, Head Troubles and Their Causes: Being a Very Brief Explanation of What Usually Produces Ailments of the Head, Face, Eyes, Nose, Ears, Throat, $\uplus c$., But Not Heretofore Known to the Public, with Some Advice Therefor [sic] (Toronto: s.n., [1898?]) (сінм/Ісмн No. 55895); and J.J. Wesley Simpson, The Microcosmic Health Pamphlet: or, the Wilford Hall Revolution (Toronto: Simpson Publishing, I890), box 25, Crane Collection.

27 Robert Hunter, Hydrotherapeutics; or, A Treatise on the Water Cure: Being a Digest of the Opinions and Experience of Some of the Most Distinguished Physicians in Europe and America, on the Curative Virtues of Water. To Which Are Added the Voluntary Acknowledgments of a Few Influential Patients, in Gratitude for Benefit Derived from Its Use, When Every Other Means Had Failed. Also, Some Practical Remarks on Typhus, Ship or Emigrant Fever, as It Occurred in This Province; with Observations on the Best Means of Prevention and Cure (Toronto: Henry Rowsell, [1848]), 3, Pamphlet No Date ' $\mathrm{H}$ ' No. 8 Hydrotherapeutics, AO.

28 Ibid., 95.

29 G.S. De Bonald, Clinique hydrothérapique de Montréal: années I 864, I865 4) 1866 (Montréal: Imprimerie de P.G. Lemoine, I 866) (сгнм/ICмн No. 60I73).

30 A Practitioner, The People's Guide to Health, Prosperity and Good Old Age, with Recommendations of Dr. J.W. Kermott's Medicines (London, C.W.: Printed at Blackburn's Steam Press, I855), Pamphlet I 855 No. 44, AO.

3 I Facts and Fallacies about Homoeopathy (s.l.: s.n., n.d.), 24, box I4, Crane Collection. 
E. Stevenson, Homoeopathy: Its Principles and Practice Explained and Illustrated, Being a Series of Letters to the Editor of the 'Independent' (Belleville, C.W.: 'Independent' Book and Job Printing Office, I860), I 3, box I I, Crane Collection. For discussion of homoeopathy in Ontario, see Connor, 'Minority Medicine,' chapter 6, especially 4I 7-8.

33 Ibid., I; 16.

34 C.E. Jarvis, Drug Uses and Abuses (s.1.: s.n., n.d.), and C.E.J., Homoeopathy Explanatory Leaflet (s.1.: s.n., I917), box 24, Crane Collection.

35 History of Homeopathy in Montreal ([Montreal: s.n., I895?]) (СІнм/Ісмн No. o1752); and Modern Homeopathy. A Review of Its History and Present Condition ([Montreal: s.n., I895?]) (сінм/Іссмн No. OI755).

36 R.J. Smith, Lecture on the History of Medicine and the Science of Homeopathy (Toronto: Printed by J. Cleland, I852), Pamphlet 1852 No. 3I, AO; and Lecture on the History of Medicine and the Science of Homeopathy (Toronto: Blackburn City Steam Press, I857) (Сінм/Ісмн No. 22632).

37 For example, one refers to Hahnemann's 'superior excellency': [Dr. Schaefer], Two Medical Systems Contrasted. Homoeopathy and Alloeopathy /Guelph: Printed at the 'Mercury' Cheap Book and Job Printing Office, I863), I6, box Io, Crane Collection.

38 M.H. Utley, Homeopathy, for the British North American Provinces. This Is a Plain Practical work, Adapted to the Comprehension of All Intelligent Minds, and Will Be Found Very Useful by New Beginners in the Practice, As a Reference. With a Lecture upon the Adaptation of the Homeopathic Treatment in Acute Diseases, Cholera, Diptheria [sic], «c., Also Diet and the Practicability of the Use of Cold Water in the Treatment of Diseases in Connection with Homeopathy (Montreal: Printed by John C. Becket, I863), vi, Pamphlet 1863 No. 30, AO.

39 Ibid., vii.

40 See, for example, Connor, 'Minority Medicine,' 290-98; Charles G. Roland and Paul Potter, An Annotated Bibliography of Canadian Medical Periodicals, I 826-I875 (Toronto: Hannah Institute for the History of Medicine, I979), item 199; Roland, 'Ontario Medical Periodicals as Mirrors of Change,' Ontario History 72 (1980): 3-15 (at 4); and Roland, 'The Unfettered Canadian,' Ontario Medicine 2 (I August 1983): 25.

4I See Connor, 'Minority Medicine,' chapter 4.

42 'Introduction and Prospectus' to The Unfettered Canadian (I 849), iii. Only one extant copy of this work now exists at the National Library of Medicine, Bethesda, Maryland. For this study, both this original copy and the microfiche version published by the Hannah Institute for the History of Medicine were used. (Both the original and the filmed copy are poor.)

43 Ibid., iv.

44 Ibid., v.

45 Barrie Dyster, 'Dick, Robert,' Dictionary of Canadian Biography, Vol. XI I 88I-I 890, 259-6I.

46 For fuller analysis of the common rhetorical style of Dick, The Unfettered Canadian, other Thomsonian literature, and its role in the reform movement 
in Upper Canada, see Jennifer J. Connor and J.T.H. Connor, 'Thomsonian Medical Literature and Reformist Discourse in Upper Canada,' Canadian Literature I3I (1991): 140-55.

47 Dick became a colporteur in $185 \mathrm{I}$, travelling extensively in the province to sell religious books, and then he established a religious journal, the Gospel Tribune, in 1853 . See Dyster; and Robert Dick, 'Colportage in Canada,' Gospel Tribune 2 (October I 855): 168-9.

48 Arza Parish, secretary of the newly formed Thomsonian Medical Reform Association, submitted the minutes of the founding meeting of the society in October I 848 in which it was resolved to collect information on the subject 'to be laid before the public in general and particularly before the members of the present Legislature, in pamphlet or other printed form,' Unfettered Canadian I (1849): 53. Dick's explanation appears on pp. 49-50.

49 Medical Criticism [No. I, 2 September I 882], I.

50 Medical Criticism, 4 and I 8 November I882, 9 December I882, 20 January I883, Io and 17 March 1883 .

5 I Medical Criticism, 9 September I882, 2.

52 Medical Criticism, 7 October 1882 , I.

53 One serialized publication, V.B. Hall's Good Canadian; or, Household Physician, actually resembles a self-help medical book in its installments offering medical recipes, botanical information and anatomical description. It may therefore be classified more accurately as a monographic serial la term borrowed from Suzanne M. Shultz and M. Sandra Wood, 'Medical Journals of Pennsylvania Before the Civil War,' Transactions and Studies of the College of Physicians of Philadelphia Ser. 5, 5 (1983): 244-70). See V.B. Hall, The Good Canadian, or Household Physician. Published in Monthly Numbers as a Medical, Philosophical, and Literary Magazine (Hamilton: s.n., I87 I).

54 Paul Rutherford, A Victorian Authority: The Daily Press in Late NineteenthCentury Canada (Toronto: University of Toronto Press, I982), 96-7. See also W.K. Kesterton, $A$ History of Journalism in Canada (Toronto: McClelland and Stewart, 1967).

55 For example, see the illustrations of Canadian Freeman, Toronto Recorder, Daily Leader, and British Herald in Edith Firth, ed., Early Toronto Newspapers, I793-I867 (Toronto: Baxter Publishing, I96I), 7, II, 23, and 26.

56 See Connor and Connor, 'Thomsonian Medical Literature.'

57 For example, E.J. Barker and John Stewart, both of Kingston, Ontario, and Lucius O'Brien of Toronto; see John W. Spurr, 'Edward John Barker, M.D.: Editor and Citizen,' Historic Kingston 27 (1979): I I 2-27; and William Canniff, The Medical Profession in Upper Canada I783-1850 (Toronto: William Briggs, 1894; reprint ed. Toronto: Hannah Institute for the History of Medicine, 1980), 536-40, 629-30. American physicians similarly owned newspapers; the founder of Eclecticism, Wooster Beach, owned two in New York: see James J. Barnes, 'Jonas Winchester: Printer, Speculator, Medicine Man,' Printing History 5 (r)(r983): I7-28 (at I8).

58 See Elizabeth Hulse, A Dictionary of Toronto Printers, Publishers, Booksellers and the Allied Trades, I798-1900 (Toronto: Anson-Cartright Editions, 
1982) for examples such as Dr. William Beattie Nesbitt ( I 89); and Dr. John Fulton (103).

59 For discussion, see Marie Tremaine, A Bibliography of Canadian Imprints, 175I-I 800 (Toronto: University of Toronto Press, 1952), item 455; and Rénald Lessard, Se soigner au Canada aux $\mathrm{XVII}^{\mathrm{e}}$ et $\mathrm{XVIII}^{\mathrm{e}}$ siècles (Ottawa: Musée canadien des civilisations, $1989 \mid, 86-7$.

60 Indeed, in the I 920 s the federal government launched whole series of pamphlets. One series for the homemaker, written by Helen MacMurchy, included such titles as The Canadian Mother's Book, How to Make Our Canadian Home, How to Prevent Accidents and Give First Aid; see Dianne Dodd, 'Advice to Parents: The Blue Books, Helen MacMurchy, M.D., and the Federal Department of Health, 1920-34, Canadian Bulletin of Medical History 8 (1991): 203-30.

6I Edwards indicates he changed from Hawkins \& Co. to Patterson \& Co. in January I 883 (Medical Criticism, I 3 January I883, I); the fact that his first printer ceased operation in 1883 (Hulse, Dictionary, I I 9 ) may have caused this move. A large fire in Toronto in April 1849 that destroyed the offices and buildings of at least two newspapers (Hulse, $x_{i}$; Firth, 5) may be related to the publishing delay for which Dick apologized (Unfettered Canadian, April 1849, 92).

62 Unfettered Canadian, February $1849,47$.

63 Unfettered Canadian, April 1849, 96; Conseil Provincial d'Hygiène, Le choléra, $\mathbf{1} 2$.

64 Tremaine, A Bibliography of Canadian Imprints, item $517 \mathrm{n}$.

65 Unfettered Canadian, February I849, 47; March 1849, 49; April I849, 96; and 'The Unfettered Canadian Extra,' verso of Medical Anti-Monopoly Petition (s.l.: s.n., n.d.) (сінм/гсмн No. 45638).

66 Unfettered Canadian, May I849, 120.

67 Dyster, 'Dick, Robert,' 260.

68 See John J. Heagerty, Four Centuries of Medical History in Canada, 2 vols. (Toronto: Macmillan, I928), I: 337-95.

69 See Dodd, 'Advice to Parents'; Tremaine, A Bibliography of Canadian Imprints, $2 \mathrm{I} \mathbf{I}$; and William Coleman, 'The People's Health: Medical Themes in Eighteenth-Century French Popular Literature,' Bulletin of the History of Medicine 5I (1977): 55-74 (at 57).

70 See Gertrude L. Annan, 'Medical Americana,' Journal of the American Medical Association 192 (1965): I 3 1-36; and William Dosité Postell, The Development of Medical Literature (New Orleans: Louisiana State University School of Medicine, 1943). 
